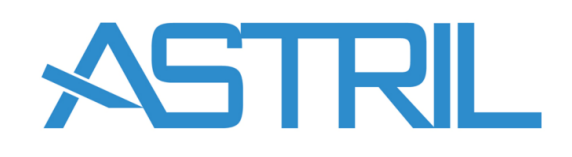

Associazione Studi e Ricerche

Interdisciplinari sul Lavoro

Working Paper $n^{\circ}$ 41/2019

\title{
MORE INSECURE AND LESS PAID? THE EFFECT OF PERCEIVED JOB INSECURITY ON WAGE DISTRIBUTION
}

Sergio Scicchitano, Marco Biagetti, Antonio Chirumbolo

Anno 2019

ISSN 2280 - 6229 -Working Papers - on line

ASTRIL (Associazione Studi e Ricerche Interdisciplinari sul Lavoro) 
I Working Papers di ASTRIL svolgono la funzione di divulgare tempestivamente, in forma definitiva o provvisoria, i risultati di ricerche scientifiche originali. La loro pubblicazione è soggetta all'approvazione del Comitato Scientifico.

esemplare fuori commercio

ai sensi della legge 14 aprile 2004 n.106

Per ciascuna pubblicazione vengono soddisfatti gli obblighi previsti dall'art. 1 del D.L.L. 31.8.1945, n. 660 e successive modifiche.

\section{Comitato Scientifico}

Sebastiano Fadda

Franco Liso

Arturo Maresca

Paolo Piacentini

\section{REDAZIONE:}

\section{ASTRIL}

Università degli Studi Roma Tre

Via Silvio D'Amico, 77 - 00145 Roma

Tel. 0039-06-57335751; 06-57335723

E-mail: astril@uniroma3.it

http://host.uniroma3.it/associazioni/astril 


\title{
More insecure and less paid? The effect of perceived job insecurity on wage distribution
}

\author{
Sergio Scicchitano $^{\mathrm{a}, \mathrm{b}^{*}}$, Marco Biagetti ${ }^{\mathrm{c}}$, Antonio Chirumbolo ${ }^{\mathrm{d}}$ \\ ${ }^{a}$ INAPP (National Institute for the Analysis of Public Policies), Rome, Italy \\ ${ }^{b}$ GLO (Global Labor Organization), Essen, Germany \\ ${ }^{c}$ Presidency of the Council of Ministers, Government of Italy, Rome, Italy \\ ${ }^{d}$ University "La Sapienza" of Rome, Department of Social and Developmental Psychology
}

\begin{abstract}
This article employs a Counterfactual Decomposition Analysis (CDA) using both a semi-parametric and a non-parametric method to examine the pay gap, over the entire wage distribution, between secure and insecure workers on the basis of perceived job insecurity. Using the 2015 INAPP Survey on Quality of Work, our results exhibit a mirror J-shaped pattern in the pay gap, with a significant sticky floor effect, i.e. the job insecurity more relevant at the lowest quantiles. This pattern is mainly due to the characteristics effect, while the relative incidence of the coefficient component accounts roughly for 22 up to $36 \%$ of the total difference, being more relevant at the bottom of the wage distribution.
\end{abstract}

Keywords: Job (in)security, Counterfactual distribution, Semi-parametric methodology, Nonparametric methodology, Wage gap, Blinder/Oaxaca, Quantile regression, Italy,

JEL classification: J31, J82, C14.

\footnotetext{
"We thank Giovanni Gallo, Stefanie Gundert, Paolo Severati, Wen Wang, participants at seminar in the University of Modena and Reggio Emilia, at the Annual EAEPE Conference, Nice, 6-8 September 2018, at BSA Work, Employment and Society Conference, Belfast 12-14 September 2018, at Counterfactual Methods for Policy Impact Evaluation (COMPIE 2018) Conference, Berlin 26-28 September 2018, at II Annual Conference of Astril " Technology, Employement, Institutions" University Roma Tre, 13-14 December 2018 for useful comments. The views and opinions expressed in this article are those of the authors and do not necessarily reflect those of the Institutions. Corresponding author. E-mail: s.scicchitano@inapp.org.
} 


\section{Introduction}

On 26 February 1997 Alan Greenspan, the former chairman of the US Federal Reserve, in his Congressional hearing, explaining why «the rate of pay increase still was markedly less than historical relationships with labour market conditions would have predicted» said: «Atypical restraint on compensation increases has been evident for a few years now and appears to be mainly the consequence of greater worker insecurity [...] The unanswered question is why this insecurity persisted even as the labour market, by all objective measures, tightened considerably» ${ }^{1}$.

Contemporary society is characterized by high levels of uncertainty which saturate almost all domains of everyday life (Baumann, 2007), including the labour market. From a general perspective, the intensified global economic competition, occurred in recent decades, has put strong pressure on many organizations, often changing their structure. In fact, in order to face difficulties and maintain a high level of effectiveness and competitiveness, most organizations have undertaken drastic measures such as merging, downsizing, acquisitions, layoffs, that have frequently led to reducing the workforce or changing its composition (e.g. higher proportion of temporary workers).

In recent decades great concern has been given to rising wage inequality and Job Insecurity (JI henceforth) in many developed countries. The difficult macroeconomic environment since 2007 has been characterized by slower nominal wage growth and lower job quality, due to greater labour market insecurity in most OECD countries (OECD 2016). This macro scenario has also changed the nature of work, moving from a traditional secure perspective into a more insecure and instable one. The current risk is that this situation may be exacerbated by technological change and the rise of the so called "gig economy", considered as one of the sign of this epochal modification (Friedman 2014). As occupational risk - such as becoming unemployed or having a temporary contract increases, the feelings and the perceptions of JI among the employees also surge. As a matter of

\footnotetext{
${ }^{1}$ See the Testimony of Chairman Alan Greenspan Federal Reserve's semiannual monetary policy report Before the Committee on Banking, Housing, and Urban Affairs, U.S. Senate February $26,1997$. https://www.federalreserve.gov/boarddocs/hh/1997/february/testimony.htm.
} 
fact, nowadays JI is considered one of the most powerful stressor at work (Sverke and Hellgren, 2002).

The psychological, somatic and behavioral consequences of perceived JI on individuals have been widely investigated (Sverke and Hellgren, 2002), but the evidence on the relationship between subjective JI and wage is scant. Empirical articles evaluating the effect of perceived JI on wage have focused on its average level (Blanchflower 1991, Maurin and Postel-Vinay 2005, Cambell et al. 2007). The most relevant aspects concerning its distribution, which in this type of analysis are of more interest to a policy maker, have been left out.

To the best of our knowledge, our article is the first attempt to estimate the association between perceived JI and wage along the whole wage distribution. We fill this gap of current economic literature, using the 2015 INAPP Survey on Quality of Work (InappQoW). This article employs a Counterfactual Decomposition Analysis (CDA) using both a semi-parametric and a nonparametric method to examine the pay gap over the entire wage distribution between two groups of workers on the basis of perceived job insecurity. In addition, we estimate whether and to what extent this pay gap is attributed more to differences in labour market characteristics between the two groups of workers or to differences in rewards that the two groups receive for their characteristics in the Italian labour market.

Our results show that the mean estimates of the JI pay gap are likely to conceal important differences along the wage distribution for secure and insecure workers. The pay gap exhibits an interesting mirror J-shaped pattern along the whole wage distribution, with the lowest value around the $80^{\text {th }}$ percentile, thus giving evidence of a significant sticky floor effect. Such pattern is mainly due to the characteristics effect, while the relative incidence of the coefficient component is more relevant at the bottom of the wage distribution.

The article is organized as follows: section two reports previous literature on the perceived job-insecurity. Section three describes the semi-parametric and the non-parametric decomposition 
methods. In Section four, data are illustrated. Empirical results are shown in section five, while section six concludes.

\section{Previous literature on perceived job-insecurity}

Currently, JI is a topic that crossways a growing literature in different disciplines such as psychology, sociology, political science and only marginally economics (Burchell, 2009, Erlinghagen, 2008, Gallie et. Al 2017, Helbling, and Kanji, 2017, Koutentakis, 2008 Lubke, and Erlinghagen 2014), with several definitions. There are many objective situations in which a job position can be at risk and insecure. For instance, having a temporary contract that will end soon or being hired in an organization which is facing hard times of crisis and will possibly undertake massive dismisses are surely conditions of "objective" JI and occupational risk. Nevertheless, JI represents a fundamental "subjective" experiences (Greenhalg and Rosenblatt, 1984; Sverke and Hellgren, 2002). In fact, in psychological literature JI is defined as the perceived threat and perceived probability of an involuntary job loss and the worries and concerns that relates to the future continuity of the current job (De Witte, 1999; Hartley, Jacobson, Klandermans and van Vuuren, 1990; Sverke and Hellgren, 2002; Sverke, Hellgren, Näswall, Chirumbolo, De Witte and Goslinga, 2004). If, on one hand, the "subjective" perception of JI is strongly linked to the "objective" situation, on the other hand empirical and theoretical research has shown that these two aspects do not completely overlap (De Cuyper, and De Witte, 2007) and that, as we will note later, the "subjective" experience of JI has consequences that are independent from "objective" JI (Sverke and Hellgren, 2002). This is why perceived JI is more interesting, as well as more suitable, to investigate.

Accordingly, the perception of JI principally rely on the 'objective' conditions in which individuals work, the most important predictors being macro and socio-demographical variables (Ashford, Lee and Bobko, 1989; Sverke and Hellgren, 2002). Individual perception of JI is related to the national level of unemployment and the economic situation (De Weerdt, De Witte, Catellani 
and Milesi, 2004; Nätti, Happonen, Kinnunen and Mauno, 2005). Moreover, also background characteristics which indicate a weak labor market situation are related to individual perception of JI. Research shows that low skilled individuals, blue collar-workers, workers in the industrial sector, employees which face organizational change, and those that have a temporary job contract, typically experience a higher level of perceived JI (Näswall and De Witte, 2003; Keim, Landis, Pierce, and Earnest, 2014). These kinds of workers, in fact, have in general a higher probability of losing their job and being fired.

Despite that, individual psychological variables may affect perception of JI which shows considerable amount of variance that is not accounted for by the objective situation. Different individuals embedded in the same objective situation do in fact perceive different level of JI since the very same objective situation can be appraised in various ways by different workers (Hartley et al., 1991; Klandermans and van Vuuren, 1999). Moreover, while some individuals may perceive high level of JI even when the objective situation is secure and their job continuity is not at risk (for example permanent workers employed in public sector), on the contrary others that may not feel particularly insecure about their jobs (for example those with higher level of employability) even though their objective situation is at risk (Klandermans and van Vuuren, 1999).

A recent study investigated the relationship between individual JI and JI climate over time among 419 employees working in Flanders (Låstad, et al., 2016). Findings appear to indicate that perceptions of individual JI were related with a climate of JI at workplace six months later, whereas no evidence was found for the opposite effect, namely JI climate do not seems to have a primary effect on individual JI. The authors suggest, therefore, that JI might origins in the individual's perceptions and expands only afterwards to comprise perceptions of a more general JI climate at the workplace.

This subjective variability in the perception of JI is very interesting since it has being shown to have a substantial impact on a number of individual and organizational outcomes, with important 
implications, over and above the "objective" JI (e.g. Chen and Chang, 2008; Gilboa, Shirom, Fried and Cooper, 2008; Sverke and Hellgren, 2002).

Individuals with higher perceived JI have in general a worst health: those people report higher levels of physical complaints and stress, and poorer psychological well-being (Chirumbolo and Hellgren, 2003; De Witte, 1999; De Witte, Vander Elst and De Cuyper, 2015; De Witte, Pienaar, and De Cuyper, 2016). Subjective JI negatively impact also other personal outcomes in individuals' life: Higher perceived JI is related to poorer family relationships (Larson, Wilson and Beley, 1994; Mauno and Kinnunen, 1999), lower life satisfaction (De Cuyper, Bernhard-Oettel, Berntson, De Witte and Alarco, 2008; Lim, 1997), reduced self-esteem (Kinnunen, Feldt and Mauno, 2003), impaired inclination towards daily consumption and limited major life decisions (Lozza, Castiglioni, Bonanomi, in press).

Perception of high JI is also negative for the optimal functioning of the organizations. Employees that are worried with their situation at the workplace will be detracted from their focus on work, impairing their performance (Reisel, Chia, Maloles and Slocum, 2007), and will develop withdrawal attitudes and cognitions, reducing their commitment to the job and the organization itself. These patterns of findings were confirmed by many empirical studies (for review see Chen and Chang, 2008; De Witte, 2005; Gilboa, Shirom, Fried and Cooper, 2008; Sverke, Hellgren and Naswall, 2002).

In particular, investigations showed that higher perceived JI is related to lower organizational commitment and job satisfaction (e.g., Ashford, Lee and Bobko, 1989; Callea, Urbini, Ingusci and Chirumbolo, 2016; Chirumbolo and Hellgren, 2003; Davy, Kinicki and Scheck, 1997; De Cuyper and De Witte, 2006; Hellgren, Sverke and Isaksson, 1999), lower organizational citizenship behavior (Chirumbolo, Urbini, Callea, Lo Presti and Talamo, 2017; Piccoli, Urbini, Callea, Chirumbolo and De Witte, 2017; Reisel et al., 2010), lower work engagement (Chirumbolo, Urbini, Callea, Lo Presti and Talamo, 2017; De Cuyper et al., 2008; Stander and Rothmann, 2010), worst self-rate task performance (Chirumbolo and Areni, 2010; Chirumbolo, Urbini, Callea, Lo Presti and 
Talamo, 2017; LePine, Podsakoff, and LePine, 2005; Piccoli et al., 2017; Reisel, et al., 2007), less identification with the organization (Chirumbolo, Urbini, Callea and Talamo, 2017). On the other hand, higher perceived JI is usually related to more turn over intentions (Chirumbolo and Hellgren, 2003; Dekker and Schaufeli, 1995) and more deviant or counterproductive behaviors in the workplace (Chirumbolo, 2015; Lim, 1997; Reisel et al., 2010). It is worth to note that the vast majority of the aforementioned results highlighted the impact of subjective JI controlling for the most important background and socio-demographical variables (such as gender, age, tenure, contract type, occupational status and the like).

Focusing on the economic literature, few papers have investigated the effect of perceived JI on the average level of wages. Maurin and Postel-Vinay (2005) demonstrate that perceived job security and wage are two substitute components in the functioning of European labour markets. Hubler and Hubler (2010) show that perceived and objective JI has a negative effect on wages in both the UK and Germany. Cambell et al. (2007) find that in Britain the fear of unemployment has a negative and significant effect on the mean level of wages. In Blanchflower (1991) it is shown that the concern for unemployment depresses pay significantly. Workers who expect to be redundant receive, on average, $9 \%$ less in the UK and $22 \%$ less in the US. It is important to note that when trying to assess the effects of policy variables, policy maker is more interested in the effects on the whole distribution of a variable, rather than on its average. This is particularly relevant in the case of social policies tailored to deal with wage inequality. Thus, a study investigating the effects on the average income actually leaves out the most relevant aspects concerning its distribution. We add to the existing literature, evaluating the effects of the JI on the income distribution as well as on its average.

With regard to Italy, in the context of the great economic and financial crisis-it has shown both a quite large increase in JI and a decline in the hourly real wage, even more clearly than the other OECD countries. (OECD 2016). Some articles evaluated the wider labour market reform package adopted at the end of 2014 - Law 183 of 2014, known as the "Jobs Act" - aimed at both 
reducing labour market segmentation between fixed-term and open-ended job contracts and stimulating job creation (Cirillo et al. 2017, Sestito and Viviano 2018). Catalano and Pezzolla (2017) using a Dynamic Stochastic General Equilibrium (DSGE) model to evaluate the so-called Jobs-Act find that the positive impact on GDP and aggregate demand comes at the expense of a reduction in the labour income share and the average wage. With respect to income support measures, some authors noted that, although improved compared to the past (see the scheme, called Reddito di Inclusione, introduced at the beginning of 2018) the Italian Welfare State needs further improvements to cope with the demographic and technological changes in progress (Sacchi 2018). Focusing on the empirical studies on the wage effect, attention has been devoted on the pay gap between permanent and temporary contracts (Berton et al. 2012, Bosio 2014), while the effect of perceived JI on wage has been neglected. Our paper adds to the current literature by exploiting both a semi-parametric and a non-parametric decomposition approach to provide new insights into the nature and sources of the pay gap due to perceived JI across dependent workforce in Italy.

\section{Empirical specification}

\subsection{B-O decomposition and a semi-parametric estimation}

By means of the Blinder-Oaxaca (B-O) decomposition a researcher can explain how much of the difference in the mean wage across two groups is due to group differences in the levels of explanatory variables, and how much is due to differences in the magnitude of regression coefficients (Oaxaca 1973; Blinder 1973). If S and I are the two groups of secure and insecure workers, the mean wage difference to be explained $(\Delta \bar{y})$ is simply the difference in the mean wage for observations in those two groups, denoted $\bar{y}_{S}$ and $\bar{y}_{I}$, respectively:

$$
\Delta \bar{y}=\bar{y}_{S}-\bar{y}_{I}
$$


In the context of a linear regression, the mean wage for group $\mathrm{W}=I, S$ can be expressed as $\overline{\mathrm{y}}_{\mathrm{W}}=\overline{\mathrm{X}}_{\mathrm{W}}^{\prime} \hat{\beta}_{W}$, where $\bar{X}_{\mathrm{W}}$ contains the mean values of explanatory variables and $\hat{\beta}_{W}$ the estimated regression coefficient. Hence, $\Delta \bar{y}$ can be rewritten as:

$$
\Delta \bar{y}=\overline{\mathrm{X}}_{\mathrm{S}}^{\prime} \hat{\beta}_{S}-\overline{\mathrm{X}}_{\mathrm{I}}^{\prime} \hat{\beta}_{I}
$$

The twofold approach splits the mean outcome difference with respect to a vector of nondiscriminatory coefficients $\hat{\beta}_{R}$. The wage difference in (2) can then be written as

$$
\Delta \bar{y}=\left(\bar{X}_{\mathrm{S}}-\bar{X}_{\mathrm{I}}\right)^{\prime} \hat{\beta}_{R}+{\overline{X^{\prime}}}_{\mathrm{S}}\left(\hat{\beta}_{S}-\hat{\beta}_{R}\right)+{\overline{\mathrm{X}^{\prime}}}_{\mathrm{I}}\left(\hat{\beta}_{R}-\hat{\beta}_{I}\right)
$$

In eq. (3) the first term is the explained component while the sum between the second and the third term is the unexplained component.

While the Ordinary Least Squares (OLS) method provides estimates for the conditional mean exclusively, the Quantile Regression (QR) technique allows for the estimation of the whole conditional wage distribution. Moreover, QR estimates capture changes in the shape, dispersion and location of the distribution, while OLS estimates do not. This can be a source of misleading relevant information on the wage distribution for secure and insecure workers. Put in another way, the QR method (Koenker and Bassett 1978), seems to be more interesting, and more appropriate in this context: the $\theta^{\text {th }}$ quantile of a variable conditional on some covariates can be accounted for and the effect of those covariates at selected quantiles of the distribution can be estimated.

If $y_{i}$ is the dependent variable and $x_{i}$ the vector of the chosen explanatory variables. The relation is given by: 


$$
y_{i}=x_{i} \beta(\theta)+\varepsilon_{i} \quad \text { with } \quad F_{\varepsilon}^{-1}(\theta \mid X)=0
$$

where $F_{\varepsilon}^{-1}(\theta \mid X)$ represents the $\theta^{\text {th }}$ quantile of $\varepsilon$ conditional on $\mathrm{x}$. The estimated $\theta^{\text {th }}$ quantile is obtained by solving the following equation:

$$
\min _{\beta(\theta)}\left\{\sum_{\left(i: y_{i} \geq x_{i} \beta(\theta)\right)}^{N} \theta\left|y_{i}=x_{i} \beta(\theta)\right|+\sum_{\left(i: y_{i} \leq x_{i} \beta(\theta)\right)}^{N}(1-\theta)\left|y_{i}=x_{i} \beta(\theta)\right|+\right\}
$$

and $\beta(\theta)$ is chosen to minimize the weighted sum of the absolute value of the residuals.

Once the QR coefficients have been estimated, the differences at the selected quantiles of the wage distribution between the two groups can be divided into one component based on the differences in characteristics and another based on the differences in coefficients across the wage distribution. As argued by Melly (2005), in the classic Blinder-Oaxaca (B-O) decomposition procedure, the exact split of the average wage gap between two groups is due to the assumption that the mean wage conditional on the average values of the regressors is equal to the unconditional mean wage. In other words, if one chooses to frame the QR with the B-O methodology, he/she will elicit biased results. For this reason we chose to apply a procedure to single out the two above mentioned components from the decomposed differences at given quantiles of the unconditional distribution. Firstly, the conditional distribution is estimated through the Q; secondly it is integrated over the range of covariates.

Representing with $\hat{\beta}=\left(\hat{\beta}\left(\theta_{1}\right), \ldots \hat{\beta}\left(\theta_{j}\right), \ldots \hat{\beta}\left(\theta_{J}\right)\right)$ the vector of quantile regression parameters estimated at $\mathrm{J}$ different quantiles $0<\theta_{j}<1$ with $j=1, \ldots \ldots . . J$ and integrating over all of the quantiles and observations, an estimator of the $\tau^{\text {th }}$ unconditional quantile of the (log monthly) wage is given by: 


$$
q(\tau, x, \beta)=\inf \left\{q: \frac{1}{N} \sum_{i=1}^{N} \sum_{j=1}^{J}\left(\theta_{j}-\theta_{j-1}\right) 1\left(x_{i} \hat{\beta}\left(\theta_{j}\right) \leq q\right) \geq \tau\right\}
$$

where $1\left({ }^{\prime}\right)$ is the indicator function. Thus, the counterfactual distribution can be estimated by replacing either the computed parameters of the distribution of characteristics for secure or insecure workers. The difference at each quantile of the unconditional distribution can be decomposed into the two above mentioned components as follows:

$$
q\left(\theta, x^{i}, \beta^{i}\right)-q\left(\theta, x^{s}, \beta^{s}\right)=\left[q\left(\theta, x^{i}, \beta^{i}\right)-q\left(\theta, x^{i}, \beta^{s}\right)\right]+\left[q\left(\theta, x^{i}, \beta^{s}\right)-\left(\theta, x^{s}, \beta^{s}\right)\right]
$$

The right hand term in the first brackets constitutes the difference in rewards that the two groups of workers receive for their labour market characteristics (i.e. the counterfactual distribution), while that in the second brackets is the effect of differences in labour market characteristics between secure and insecure workers. This is a semi-parametric-method because the QR framework does not need any distributional assumption while at the same time allows the same covariates to have an influence all over the conditional distribution.

To estimate the standard errors and confidence intervals, the bootstrap method can be used to replicate the above procedure. In this study 200 replications were performed.

\subsection{The Inverse Probability Weighting approach as a non-parametric estimation}

In order to correct for selection bias in the self-perception of JI for the two groups of workers, we also estimate the wage distributions by adopting a non-parametric framework, which allows for an analysis without imposing any shape at the outset.

Indeed, after performing the Oaxaca-Blinder and Melly's decompositions, we adopt a variant

of the Inverse Probability Weighting (IPW) approach firstly proposed by Di Nardo, Fortin and 
Lemiex (DFL, 1996) and estimate quantiles for two counterfactual distributions, one if every worker were secure at his/her job, the other if they were all insecure. The IPW approach has been proved to be efficient (see Hirano, Imbens and Ridder, 2003) and particularly suitable when the aim of the researcher is, as in our case, the decomposition of the overall difference in the distributions of the outcome variable into its explained and unexplained component often called "aggregated" decomposition $^{2}$. This non parametric method needs milder assumptions than those on which methods based on the decomposition at quantiles are built (for a detailed discussion on advantages and limitations of these methods see Firpo, Fortin and Lemieux, 2011). Furthermore, with the IPW, we are not obliged to assume the same (parametric) model across quantiles unlike in Melly's (2005).

In the first stage the conditional probability of being (in)secure at work given a set of characteristics is estimated by using a probit model of the following form:

$$
\operatorname{Pr}(\mathrm{s}=11 \mathrm{x})=\phi(\mathrm{x})
$$

where $s$ is the dummy variable assuming value 1 if the individual $i=1,2, \ldots \ldots, N$ (where $N$ is the sample size) is secure at work and $\mathrm{x}$ is the same vector of variables used for the $\mathrm{B}-\mathrm{O}$ and the $\mathrm{QR}$ decompositions ${ }^{3}$. In other words the $x$ is the same vector of variables used and expected to be associated with the probability of being secure at work. The predicted values from model (8) are used for building up the following re-weighting functions:

$$
\theta_{0}=\frac{1-\operatorname{Pr}(\mathrm{s}=1)}{1-\operatorname{Pr}(\mathrm{s}=1 \mid \mathrm{x})}
$$

\footnotetext{
${ }^{2}$ Another type is the "detailed" decomposition, where the interest lies in estimating the contribution of each
} covariate to the overall difference.

\footnotetext{
${ }^{3}$ Results from the probit model are shown in table A1 in Appendix.
} 


$$
\theta_{1}=\frac{\operatorname{Pr}(\mathrm{s}=1)}{\operatorname{Pr}(\mathrm{s}=1 \mid \mathrm{x})}
$$

Those functions are later used in the otherwise non-parametric Parzen-Rosenblatt kernel density estimator to build up two so-called counterfactual densities of wages, i.e. the density that would prevail if none of the employees were secure at work and the density if every worker were secure:

$$
\hat{f}_{N, h(w)}=\frac{1}{N} \sum_{i=1}^{N} \frac{\hat{\theta}_{j}}{h} K\left(\frac{w-w_{i}}{h}\right) \quad j=0,1
$$

where $w$ is the (natural log of the) wage and $K$ is the kernel density function that satisfies:

$$
\int_{-\infty}^{\infty} K(p) d p=1^{4}
$$

Eq. (11) is the empirical counterpart of the two following distributions:

$$
f^{n s}(w)=\int \theta_{n s} g^{n s}(w \mid x) l(x \mid s=0) d x
$$

and

${ }^{4}$ Many kernel functions can be used to the scope. In our exercise we chose the Gaussian kernel evaluated at ( $w-w_{i}$ ) given the bandwidth $h$. Our choice of the kernel is due to its property of monotonicity of peaks and valleys w.r.t. changes in the smoothing parameters, which proves to be useful when comparing distributions (Sheather, 2004). For what concerns the bandwidth, our choice has fallen on the Cross Validation (CV) method: it is suitable as there is no need to make assumptions about the smoothness to which the unknown density belongs (Loader, 1999). 


$$
f^{s}(w)=\int \theta_{s} g^{s}(w \mid x) l(x \mid s=1) d x
$$

for insecure and secure workers respectively.

In Eq. (12) and (13) $\theta_{n s}$ and $\theta_{s}$ are the true re-weighting parameters, $g^{n s}(w \mid x)$ and $l(x \mid s=0)$

as well as $g^{n s}(w \mid x)$ and $l(x \mid s=1)$ are the conditional densities of wages and the distributions of the $x$ characteristics associated to the subsamples for which $s=0$ and $s=1$ respectively. The two distributions are then compared to compute the total difference conditional on the $x$ characteristics, while its explained part of is obtained by comparing the first of those distributions (that of insecure workers) with the actual density of wages

$$
f(w)=\int g(w \mid x) l(x) d x
$$

\section{Data}

The data used in this article are from the Fourth INAPP Survey on Quality of Work (InappQoW) that has been carried out in 2015 on a sample of 15,000 workers. INAPP realizes this periodical survey every four years, with the aim of measuring the concept of work quality in Italy. The project is inspired to the European Working Conditions Survey carried out by Eurofound.

We first excluded self-employed workers. The sample was then restricted to employees between 18 and 64 years. The final sample consisted of 4,155 secure and 1,239 insecure workers.

In order to measure subjective (perceived) JI included within the wage equations estimated in section 5, we refer to a specific question which was asked in the InappQoW. Individuals who are currently in employment are asked: "In the next 12 months I could not have more work, in spite of myself". Individuals were required to respond "Yes" or "Not".

The logarithm of the monthly net wage is regressed on a set of covariates representing: 
(i) individual characteristics: age and its squared, gender, household ability to make ends meet (3 categories indicating "simply", "with some difficulties", and "with many difficulties" education (eight categories based on the highest level achieved), education of father (eight categories based on the highest level achieved), work experience;

(ii) job characteristics: part-time/full-time, temporary/permanent, mobility in change job (four categories showing how many changes since the first job, "never changed", "1/2 changes job", "3/5", "more than 5", stability of job security over time (three categories given by the response to the question "by comparing your current work situation with that of January 2008, do you think the job stability has worsened, equalled or improved?"), training received in the last year, supervisory position, telework, welfare/social security contributions payment, routine tasks prevailing at work, skill mismatch, job-stress (three categories for the question “consider your stressful work?", ranging from "never" to "always or most of the time";

(iii) firm characteristics: size (measured by the number of workers in the same local unit), location in the Southern Italy (Mezzogiorno), sector of economic activity (17 dummy variables);

Table 1 shows the descriptive statistics for the sample of secure and insecure employees used in the empirical analysis. Figure 1 plots the kernel estimates of the wage density for both groups. It can be noted that the top of the monthly net wage density for secure workers is reached at a higher wage than that for insecure workers. Furthermore, the wage distribution for secure worker is clearly shifted to the right with respect to the insecure workers. As a first robustness check for the difference between the two distributions, the non-parametric Kolmogorov-Smirnov test based on the concept of stochastic dominance, is used to check for differences in all moments of the wage distribution. The concept of first order stochastic dominance allows one to establish a ranking for compared distributions. The results of the Kolmogorov-Smirnov test for the first order stochastic dominance shown in Table 2 confirm that the net monthly wages of secure workers stochastically dominate, at the 1 per cent significance level, those of insecure workers. 
Table 1

Summary statistics

\begin{tabular}{|c|c|c|c|c|c|c|c|c|c|c|}
\hline \multirow[b]{2}{*}{ Variable } & \multicolumn{5}{|c|}{ Job insecurity: no } & \multicolumn{5}{|c|}{ Job insecurity: yes } \\
\hline & Obs & Mean & Std. Dev. & Min & Max & Obs & Mean & Std. Dev. & Min & $\operatorname{Max}$ \\
\hline $\log n m w$ & 4897 & 7.267 & 0.411 & 5.298 & 10.597 & 1683 & 7.017 & 0.499 & 5.298 & 9.547 \\
\hline age & 6477 & 46.277 & 11.134 & 18 & 64 & 2194 & 42.583 & 11.725 & 18 & 64 \\
\hline dmale & 6477 & 0.516 & 0.500 & 0 & 1 & 2194 & 0.536 & 0.499 & 0 & 1 \\
\hline make_ends_meet & 6388 & 1.199 & 0.655 & 0 & 2 & 2169 & 0.925 & 0.678 & 0 & 2 \\
\hline edu_fath & 6113 & 1.853 & 1.036 & 0 & 4 & 2069 & 1.808 & 1.011 & 0 & 4 \\
\hline work_exp & 6477 & 23.883 & 11.672 & 0 & 55 & 2194 & 20.934 & 12.707 & 0 & 55 \\
\hline pasted & 6477 & 4.046 & 1.527 & 0 & 8 & 2194 & 3.626 & 1.468 & 0 & 8 \\
\hline dfull & 6477 & 0.845 & 0.362 & 0 & 1 & 2194 & 0.716 & 0.451 & 0 & 1 \\
\hline dperm & 6287 & 0.939 & 0.240 & 0 & 1 & 1959 & 0.734 & 0.442 & 0 & 1 \\
\hline mobility & 6456 & 1.038 & 1.016 & 0 & 3 & 2184 & 1.357 & 1.071 & 0 & 3 \\
\hline stability & 5823 & 1.089 & 0.635 & 0 & 2 & 1788 & 0.607 & 0.720 & 0 & 2 \\
\hline dtraining & 6477 & 0.591 & 0.492 & 0 & 1 & 2194 & 0.448 & 0.497 & 0 & 1 \\
\hline supervisor & 6477 & 0.375 & 0.484 & 0 & 1 & 2194 & 0.340 & 0.474 & 0 & 1 \\
\hline telework & 6477 & 0.160 & 0.367 & 0 & 1 & 2194 & 0.102 & 0.303 & 0 & 1 \\
\hline contr & 6447 & 0.976 & 0.154 & 0 & 1 & 2161 & 0.932 & 0.252 & 0 & 1 \\
\hline routine & 6477 & 0.689 & 0.463 & 0 & 1 & 2194 & 0.786 & 0.410 & 0 & 1 \\
\hline mismatch & 6477 & 0.195 & 0.396 & 0 & 1 & 2194 & 0.273 & 0.446 & 0 & 1 \\
\hline stress & 6477 & 1.136 & 0.543 & 0 & 2 & 2194 & 1.131 & 0.572 & 0 & 2 \\
\hline unionsize & 6477 & 253.912 & 785.857 & 1 & 9000 & 2194 & 172.809 & 659.531 & 1 & 9000 \\
\hline mezz & 6477 & 0.239 & 0.426 & 0 & 1 & 2194 & 0.279 & 0.449 & 0 & 1 \\
\hline sectors & 6477 & 9.877 & 4.761 & 1 & 17 & 2194 & 8.752 & 5.015 & 1 & 17 \\
\hline N. Observations & & & 4155 & & & & & 1239 & & \\
\hline Insecure workers (\%) & & & & & & & & $29 \%$ & & \\
\hline
\end{tabular}

Sources: Elaboration from the Fourth INAPP Survey on Quality of Labour 2015 


\section{Figure 1}

Wage distribution for workers with JI and workers woth no JI

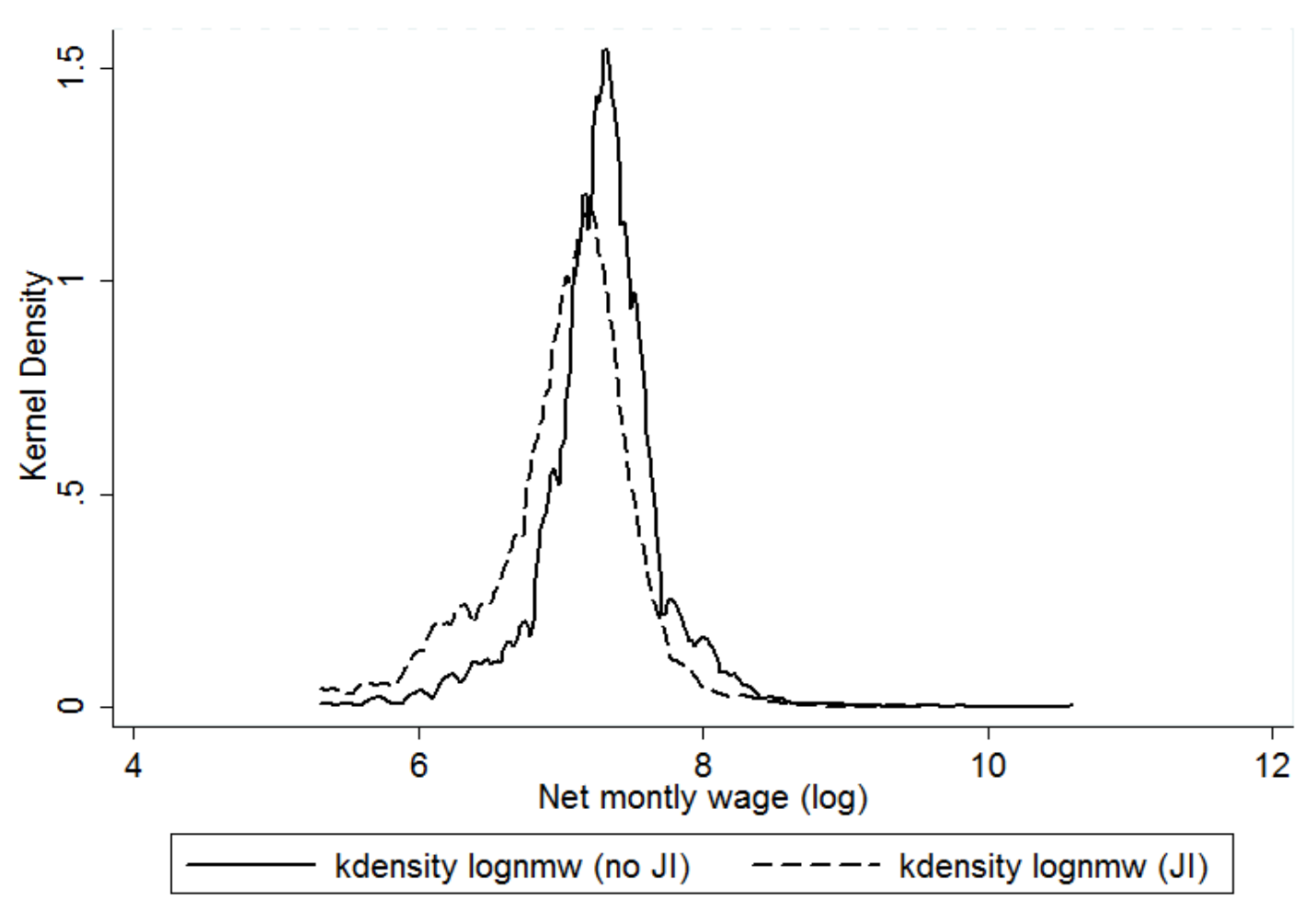

As a first robustness check for the difference between the two distributions, the nonparametric Kolmogorov-Smirnov test based on the concept of stochastic dominance, is used to check for differences in all moments of the wage distribution. The concept of first order stochastic dominance allows one to establish a ranking for compared distributions. The results of the Kolmogorov-Smirnov test for the first order stochastic dominance shown in Table 2 confirm that the net monthly wages of secure workers stochastically dominate, at the 1 per cent significance level, those of insecure workers.

\section{Results}

\subsection{Ordinary least squares and quantile regression}

As a first step, we estimate the Mincerian wage equations - separately for secure and insecure workers. The estimation results are presented in tables $3 a$ and $3 b$. In particular we show, for the two 


\section{Table 2.}

Kolmogorov-Smirnov test for comparison between workers with JI and workers with no

JI

\begin{tabular}{lccc} 
& Combined & $\mathrm{JI}=$ no & $\mathrm{JI}=\mathrm{yes}$ \\
\hline $\mathrm{KS}_{2}$ & 0.2563 & & \\
& $(0.000)$ & & \\
$\mathrm{KS}_{1}$ & & -0.2563 & 0.000 \\
& & $(0.000)$ & $(1.000)$ \\
\hline
\end{tabular}

Note: $p$ - values in parentheses

groups, respectively, the OLS coefficients as well as the conditional coefficients at nine representative quantiles: $\theta 10, \theta 20, \theta 30, \theta 40, \theta 50, \theta 60, \theta 70, \theta 80, \theta 90$.

The OLS results for those who are secure at work show that their salary is higher when they grow older, if they are men, if they do not have any difficulty in making ends meet ${ }^{5}$, if workers and their fathers have attained at least the lowest school degree (elementary school) ${ }^{6}$, if they have more work experience (even though this variable is slightly significant) and unsurprisingly if they have a full time contract, a permament job, or supervise other workers. High mobility (more than 5 changes) is found to have a not significant negative effect on the salary of the first group of workers. Stability of the job condition is also non statistically significant. Attending training courses at work has a positive effect on their salary (increasing it by about 5.8 percentage points). Interestingly, workers who sometimes work remotely from home with their own PCs are found to earn $8.2 \%$ more than those who in the secure case do not. Routinary tasks negatively affect wage of secure workers are $(-5.5 \%)$. Being stressed at work is found to be associated with higher wages as well as a larger size of the firm, while being a Southern worker is not statistically significant.

${ }^{5}$ The effect from category 0 to 1 and from 1 to 2 is increasing), thus suggesting a non-linear relation with the wage.

${ }^{6}$ The effect of the direct (i.e. of the worker) educational attainment is found to increase salary of about 5.3 percentage points, while the indirect (i.e. of their fathers) increases the salary of $2 \%$ percentage points. 
For what concerns the insecure group of workers unlike the former group, their age is found statistically significant. Fathers' educational effect on their wage is again positive. Mobility has a negative significant effect on salary starting from $3 / 5$ change: more than 5 changes has the highest negative effect. Again, having a full time job with permanent contract, with some form of job training and remote work is positively correlated to the wage level. Being stressed has a lower positive effect on salaries than in the secure group (+7.8\%). Job mismatch has a significant negative effect unlike the former regression. Finally, also in this case, the territorial predictor (i.e. being a Southern worker) is not found to have a significant effect on «unsafe» workers.

When we depart from the analysis at the conditional mean and perform simultaneous quantile regressions, the effect of age is confirmed to be positive at all the quantiles examined, even though with some difference in statistical significance: for example it is not significant at the highest decile of the insecure group.. The gender wage gap, the educational attainment, the quality of the job contract (full-time and permament), job training possibilities remain significant and positive regardless the technique used. Somewhat similar results are found for the categorical variable «make ends meet». Fathers' education is positively related to the wage and this positive contribution increases at the highest deciles: this fact hints at a hysteresis in the wage distribution across generations. The routinary task is negative and significant across the distribution and it is generally incresing. Mismatch is negative and significant only for the lowest deciles of the insecure group. (see table $3 \mathrm{a}$ and $3 \mathrm{~b}$ in the appendix)

\subsection{Counterfactual decomposition}

Table 4 reports decomposition results for the mean and for several quantiles of the wage distribution. The observed wage gaps between secure and insecure workers is shown in column (1). Columns (2) - (6) refer to the semi-parametric estimate described in section 3.1, while colums (7) (11) show the non-parametric estimate. The estimated least are also reported for comparison. Figure 
2 plots the decomposition results at each of the 99 different quantiles, with a 95 per cent bootstrap confidence interval. All estimates are significantly different from 0 at the $1 \%$ significance level.

The B-O decomposition shows a difference between mean wages of the two groups of 282 euros (1509 vs. 1227 euros). Thus the secure group earns almost 23 pp more than the insecure workers. The difference in endowments account for $3 / 4$ of this gap $(0.15$ out of 0.21 when computed in natural logs). The difference in coefficients accounts for the remaining $1 / 4$.

Table 4.

Decompositions of changes in JI wage gap and counterfactual distribution, using semi-parametric and fully non-parametric estimation

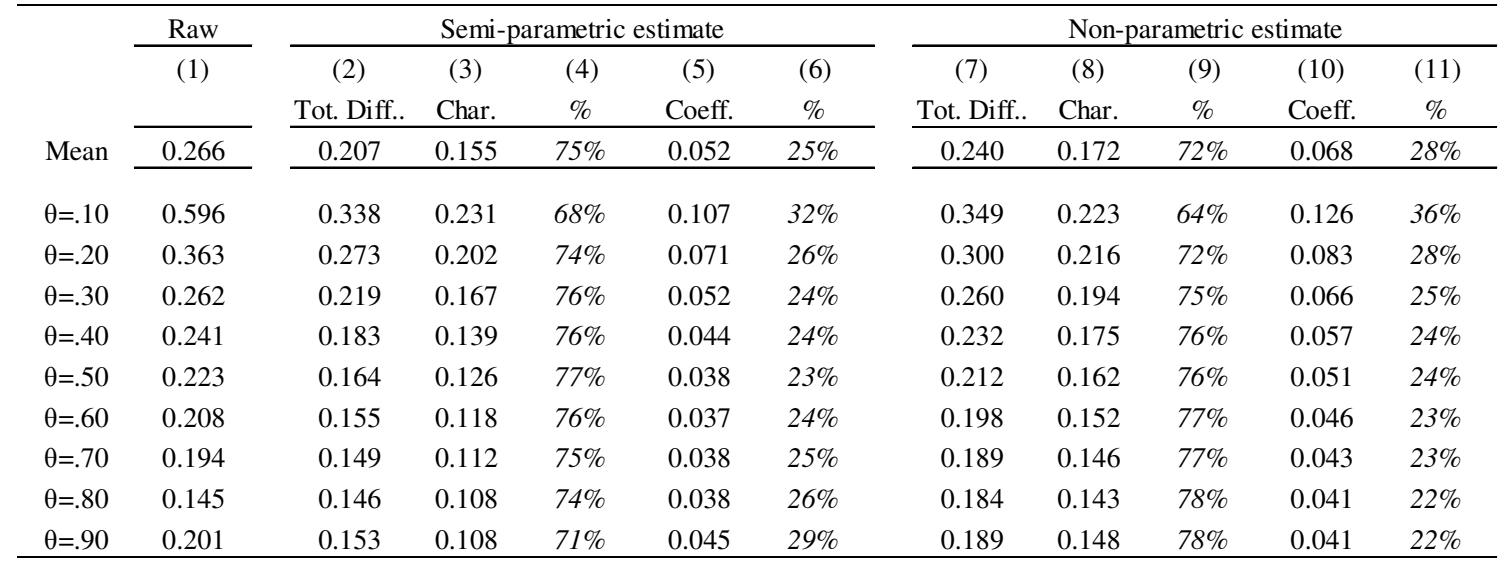

Note. Bootstrap standard errors for semi-parametric estimates are obtained with 200 replications. Mean values for the semiparametric estimation are obtained with the B-O decomposition. All coefficients are significant at $1 \%$

When the decomposition approach is extended to the whole wage distribution, it becomes evident that the contribution of differences in returns is larger than that of different covariates at each of the estimated quantiles. Moreover, the relative incidence of the coefficient component accounts roughly for 22 up to $36 \%$ of the total difference, being more relevant at the bottom of the wage distribution, thus showing a greater relevance of JI for low wages.

Figure 2 indicates that the insecure group of workers suffer from a statistically significant pay gap along all the wage distribution - as can be seen from the confidence band far from crossing the horizontal axis - after controlling for the predictors illustrated above. What is more, the pay gap seems mirror J-shaped, with the presence of a so called «sticky floor» (i.e. a situation in which the 
$10^{\text {th }}$ percentile wage gap is significantly higher than the estimated wage gap at the $50^{\text {th }}$ percentile). Indeed, as Figure 2 clearly shows, the $10^{\text {th }}$ percentile is not contained within the $95 \%$ confidence bands constructed for the $50^{\text {th }}$ percentile (the median) which also presents a rather low (even though not the lowest) overall value in the wage gap between the two groups. The pattern is slightly shifted over the right side, with the lowest value reached around the $80^{\text {th }}$ percentile.

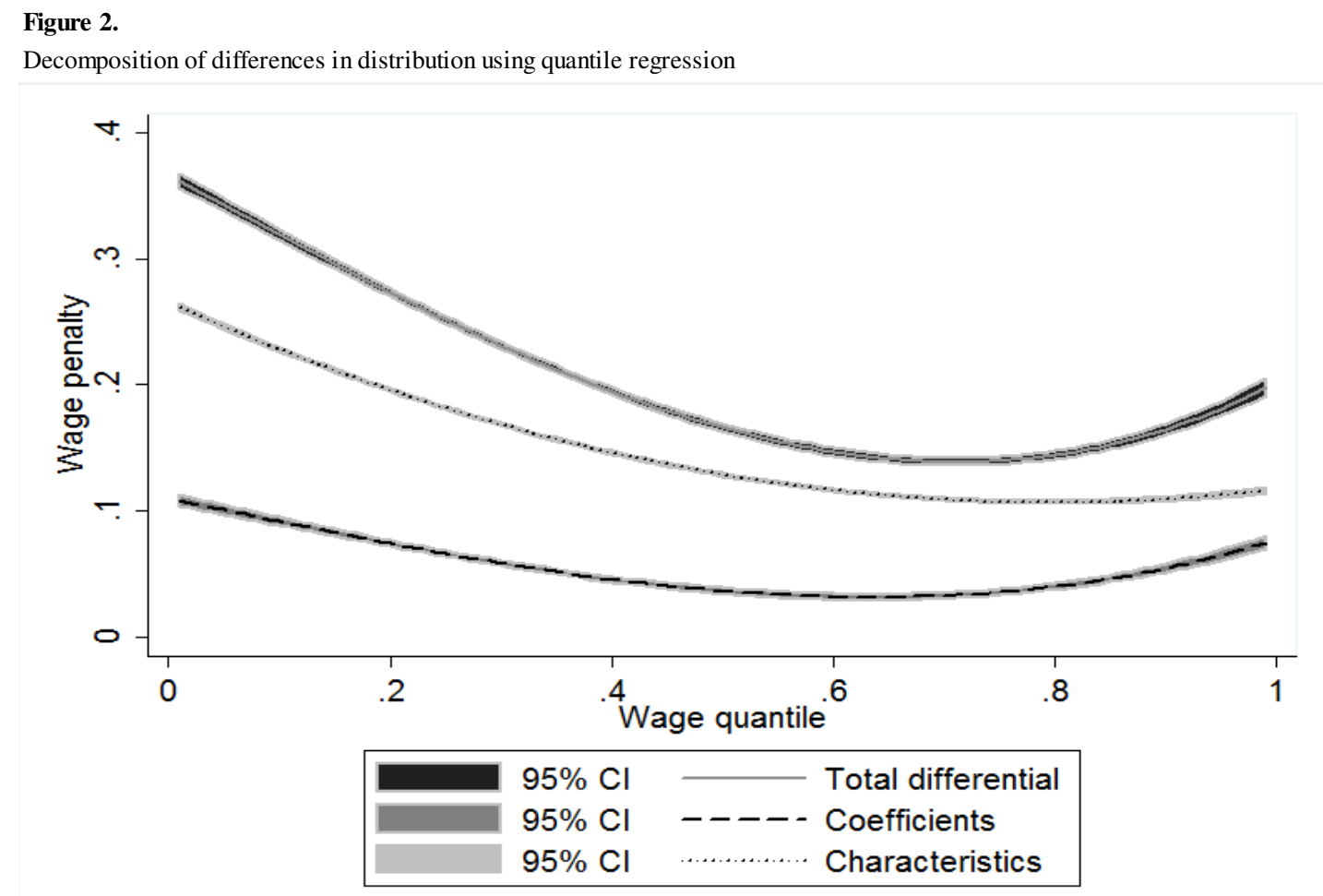

Results from the non-parametric model - table 4, colums (7) - (11) - indicate that the estimate is not substantially distorted by a selection bias, thus strengthening the sticky floor effect found with the semi-parametric method ${ }^{7}$. Figure 3 shows the smoothed difference between the actual and the the counterfactual distribution «if nobody were a secure worker». It is clear that the impact is

\footnotetext{
${ }^{7}$ The insight here is that, being the dependent variable a self-perceived JI, it already probably contains a sort of self-selection term: therefore the distortion due to self-selection is low.
} 
higher on the left tail of the distribution, consistently with the hypothesis that the wage gap between secure and insecure workers on the basis of perceived JI is higher for lowest quantiles.

\section{Figure 3 .}

IPW, smoothed difference between actual and counterfactual (if nobody were a secure worker) distribution of wages

Actual vs. Counterfactual

'If nobody were a secure worker'

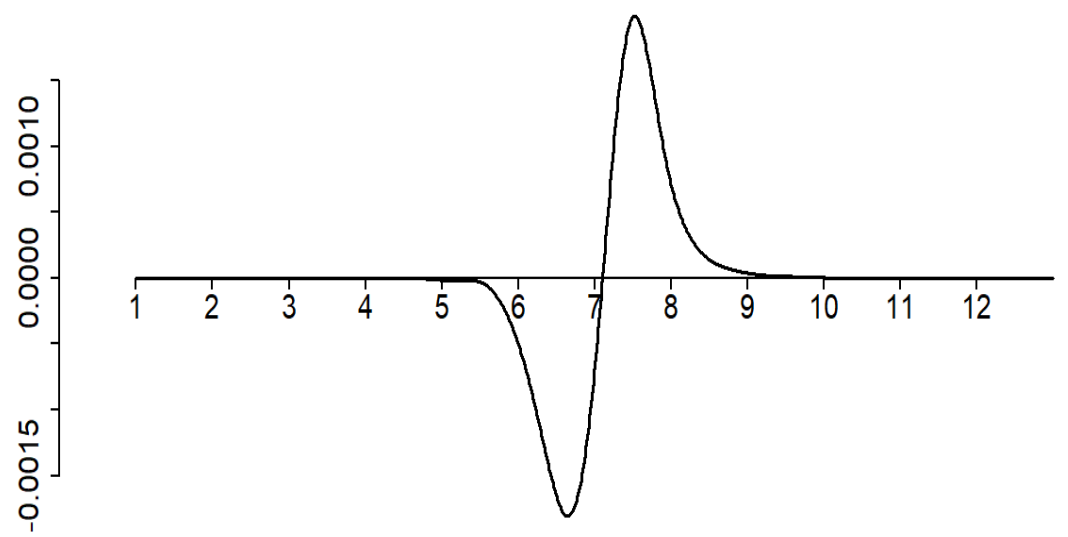

\section{Discussion and conclusions}

Using the last wave of the INAPP Survey on Quality of Work, this paper employs both a semi-parametric and a non parametric decomposition method to examine the relationship between perceived JI and wage at the mean and over the entire conditional wage distribution of the Italian dependent workforce. Results show the clear presence a mirror J-shaped pattern for the wage gap between secure and insecure workers, together with a significant sticky floor phenomenon. The counterfactual decomposition also highlights a very high endowments effect on the wage gap. Indeed, characteristics of the insecure group of workers account roughly for $2 / 3$ up to $3 / 4$ of the total difference along the wage distribution, with a higher incidence at lowest quantiles. This evidence suggests that a highly imperfect competitive labour market is at work in Italy, where greater JI may lead to workers accepting lower wages (Blanchflower, 1991). The reluctance of 
workers to leave their insecure and underpaid job reinforces the hysteresis of precariousness in the current labour market conditions, regardless of the recuperation in employment numbers achieved in the post-crisis period.

Our article has some policy indications emerged for the Italian welfare state. Indeed, to fill the wage gap, there is a need for social policies tailored to deal with income support measures. Moreover, endowments of the "unsafe group of workers" (i.e. their predictor levels in the regressions performed) should be raised. For this to happen, well-functioning and "wellintertwined" labour market and educational institutions are needed in order to strengthen the quality of job contracts (full-time and permanent being of course strongly correlated with the high level of the salary), increase employees' educational attainment, promote job training, reduce routine and mismatch during the job. This challenge appears all the more important as high wage gaps increase inequality while at the same time jeopardizing Italian social fabric. 


\section{References}

Ashford, S., Lee, C. and P. Bobko. 1989. "Content, causes, and consequences of job insecurity. A theory-based measure and substantive test." Academy of Management Journal, 32 (4): 803829. doi: $10.2307 / 256569$.

Bauman, Z. 2007. Liquid times: Living in an age of uncertainty. Cambridge: Polity Press.

Berton, F. Richiardi, M. And S. Sacchi. 2012. The political economy of work security and flexibility: Italy in comparative perspective, Policy Press.

Blanchflower, D. 1991. "Fear, Unemployment and Pay Flexibility." The Economic Journal, 101(406): 483-496. doi: 10.2307/2233554

Blinder, A. S. 1973. "Wage Discrimination: Reduced Form and Structural Estimates. The Journal of Human Resources 8 (4): 436-455. doi: 10.2307/144855

Bosio, G. 2014, “The Implications of Temporary Jobs on the Distribution of Wages in Italy: An Unconditional IVQTE Approach.” Labour, 28: 64-86. doi:10.1111/labr.12023.

Burchell, B., 2009. "Flexicurity as a moderator of the relationship between job insecurity and psychological well-being.” Cambridge Journal of Regions, Economy and Society 2(3): 365378.. doi: 10.1093/cjres/rsp021

Callea, A., Urbini, F., Ingusci, E., and A. Chirumbolo, 2016. "The relationship between contract type and job satisfaction in a mediated moderation model: The role of job insecurity and psychological contract violation". Economic and Industrial Democracy, 37(2): 399-420. doi: $10.1177 / 0143831 X 14546238$.

Campbell, D. M., Carruth A., Dickerson, A. P. and F. Green. 2007. “Job Insecurity and Wages.” The Economic Journal, 117(518): pp. 544-566. doi: 10.1111/j.1468-0297.2007.02029.x.

Catalano, M. And E. Pezzolla. 2017. “The Italian Labour Market Reform: An Evaluation of the Jobs Act Using the Prometeia DSGE Model.”, Economia Politica: Journal of Analytical and Institutional Economics 3(2): 209-238. doi: 10.1007/s40797-017-0057-z. 
Cheng, G. H. L. and D. K. S. Chan 2008. "Who suffers more from job insecurity? A meta-analytic review." Applied Psychology: an International Review, 57: 272-303. doi: 10.1111/j.14640597.2007.00312.x

Chirumbolo, A. 2015. "The impact of job insecurity on counterproductive work behaviors: The moderating role of honesty-humility personality trait." The Journal of psychology, 149(6): 554-569. doi: 10.1080/00223980.2014.916250.

Chirumbolo, A., and A. Areni, 2010. "Job insecurity influence on job performance and mental health: Testing the moderating effect of the need for closure." Economic and Industrial Democracy, 31(2): 195-214. doi: 10.1177/0143831X09358368.

Chirumbolo, A., and J. Hellgren. 2003. "Individual and Organizational consequences of Job Insecurity: a European study." Economic and Industrial Democracy, 24(2): 215-238. doi: $10.1177 / 0143831 X 03024002004$

Chirumbolo, A., Urbini, F., Callea, A., and A. Talamo. 2017. "The Impact of Qualitative Job Insecurity on Identification with the Organization: The Moderating Role of Overall Organizational Justice.” Swiss Journal of Psychology, 76(3): 117-123. doi: 10.1024/14210185/a000197

Chirumbolo, A., Urbini, F., Callea, A., Lo Presti, A., and A. Talamo. 2017. “Occupations at risk and organizational well-being: an empirical test of a job insecurity integrated model." Frontiers in psychology, 8. doi: 10.3389/fpsyg.2017.02084.

Cirillo, V., Fana, M. and D. Guarascio 2017. "Labour market reforms in Italy: evaluating the effects of the Jobs Act." Economia Politica: Journal of Analytical and Institutional Economics, Springer, 34(2): 211-232. doi: 10.1007/s40888-017-0058-2.

Cuyper, N., and H. Witte. 2006. "The impact of job insecurity and contract type on attitudes, wellbeing and behavioural reports: a psychological contract perspective." Journal of Occupational and Organizational Psychology, 79(3): 395-409. doi: 10.1348/096317905X53660 
Davy, J.A., Kinicki, A.J., and C.L. Scheck. 1997. “A test of job security’s direct and mediated effects on withdrawal cognitions." Journal of Organizational Behavior, 18: 323-349. doi: 10.1002/(SICI)1099-1379(199707)

De Cuyper, N., and H. De Witte. 2007. "Job insecurity in temporary versus permanent workers: Associations with attitudes, well-being, and behaviour. Work and Stress, 21(1): 65-84. doi: 10.1080/02678370701229050.

De Cuyper, N., Bernhard-Oettel, C., Berntson, E., De Witte, H. and B. Alarco. 2008. "Employability and Employees' Well-Being: Mediation by Job Insecurity." Applied Psychology: An International Review, 57: 488-509. doi: 10.1111/j.1464-0597.2008.00332.x.

De Weerdt, Y., De Witte, H., Catellani, P. and P. Milesi 2004. Turning right? Socio-economic change and the receptiveness of European workers to the extreme right. Results of a survey in Europe. Leuven: Hoger Instituut voor de Arbeid-KULeuven.

De Witte, H. 2005. “Job insecurity: Review of the international literature on definitions, prevalence, antecedents and consequences." SA Journal of Industrial Psychology, 31(4): 1-6. doi: 10.4102/sajip.v31i4.200

De Witte, H., Pienaar, J., and N. De Cuyper. 2016. "Review of 30 Years of Longitudinal Studies on the Association Between Job Insecurity and Health and Well-Being: Is There Causal Evidence?.” Australian Psychologist, 51(1), 18-31. doi: 10.1111/ap.12176.

De Witte, H., Vander Elst, T., and N. De Cuyper. 2015. “Job insecurity, health and well-being.”. In Sustainable working lives, edited by J. Vuori, 109-128. Springer: Dordrecht.

Dekker, S.W.A., and W. B. Schaufeli. 1995. "The effects of job insecurity on psychological health and withdrawal: A longitudinal study." Australian Psychologist, 30, 57-63. doi: $10.1080 / 00050069508259607$.

Di Nardo J., N. Fortin, and T. Lemieux. 1996. "Labour Market Institutions and the Distribution of wages 1973-1992. A Semiparametric Approach". Econometrica 64: 1001-1024. doi: $10.2307 / 2171954$. 
Erlinghagen, M. 2008. “Self-Perceived Job Insecurity and Social Context: A Multi-Level Analysis of 17 European Countries." European Sociological Review 24:183-197. https://academic.oup.com/esr/article-abstract/24/2/183/613705? redirectedFrom=fulltext.

Firpo S., N. Fortin, and T. Lemieux. 2011. "Decomposition Methods in Economics”. Handbook of Labour Economics, Elsevier. doi: 10.1016/S0169-7218(11)00407-2.

Friedman, G. 2014. "Workers without employers: Shadow corporations and the rise of the gig economy." Review of Keynesian Economics, 2(2): 171-188. https://doi.org/10.4337/roke.2014.02.03.

Gallie, D., A. Felstead, F. Green, and H. Inanc. 2017. "The hidden face of job insecurity, Work, Employment and Society." British Sociological Association, vol. 31(1), pages 36-53, February. doi: 10.1177/0950017015624399.

Gilboa, S., A. Shirom, Y. Fried, and C. Cooper. 2008. “A meta-analysis of work demand stressors and job performance: Examining main and moderating effects.” Personnel Psychology, 61, 227-271. https://onlinelibrary.wiley.com/doi/abs/10.1111/j.1744-6570.2008.00113.x.

Greenhalgh, L., and Z. Rosenblatt. 1984. "Job insecurity: Toward conceptual clarity.” Academy of Management review, 9(3), 438-448. doi: 10.2307/258284.

Hartley, J., D. Jacobson, B. Klandermans, and T. Van Vuuren. 1990. “Job insecurity: Coping with jobs at risk." Sage Publications. https://uk.sagepub.com/en-gb/eur/job-insecurity/book202465. Helbling, L., and S. Kanji. 2018. "Job insecurity: Differential effects of subjective and objective measures on life satisfaction trajectories of workers aged 27-30 in Germany." Social Indicators Research. 137: 1145. https://doi.org/10.1007/s11205-017-1635-z.

Hellgren, J., M. Sverke, and K. Isaksson. 1999. "A two-dimensional approach to job insecurity: Consequences for employee attitudes and well-being." European Journal of Work and organizational Psychology, 8, 179-195. doi: 10.1080/135943299398311. 
Hirano K., G. W. Imbens, and G. Ridder. 2003. "Efficient Estimation of Average Treatment Effects Using the Estimated Propensity Score." Econometrica 71: 1161-1189. https://doi.org/10.1111/1468-0262.00442.

Hübler, D., and O. Hübler. 2010. “The Link between Job Security and Wages: A Comparison between Germany and the UK.” Schmalenbach Business Review (sbr), LMU Munich School of Management, January. 62: 45. https://doi.org/10.1007/BF03396797.

Keim, A. C., R. S. Landis, C.A. Pierce, and D.R. Earnest. 2014. "Why do employees worry about their jobs? A meta-analytic review of predictors of job insecurity." Journal of Occupational Health Psychology, 19(3), 269-290. doi: 10.1037/a0036743.

Kinnunen, U., T. Feldt, and S. Mauno. 2003. "Job insecurity and self-esteem: Evidence from cross lagged relations a 1 year longitudinal sample.” Personality and Individual Differences, 35, 617-632. https://doi.org/10.1016/S0191-8869(02)00223-4.

Klandermans, B., and T. van Vuuren. 1999. "Job insecurity: introduction”. European Journal of Work and Organizational Psychology, 1(2), 145-155.

Koenker, R. and G. Bassett. 1978. "Regression quantiles". Econometrica, 46, 33- 50. doi: $10.2307 / 1913643$.

Koutentakis, F. 2008. "The effect of temporary contracts on job security of permanent workers." Economics Letters, Elsevier, vol. 101(3), pages 220-222, December. https://doi.org/10.1016/j.econlet.2008.08.007.

Larson, J. H., S. M. Wilson, and R. Beley. 1994. “The impact of job insecurity on marital and family relationships." Family Relations, 43, 138. doi: 10.2307/585315

Låstad, L., T. Van der Elst T., and H. De Witte. 2016. "On the reciprocal relationship between individual job insecurity and job insecurity climate." Career Development International, Vol. 21 Issue: 3, pages 246-261, https://doi.org/10.1108/CDI-03-2015-0046.

LePine, J. A., N. P. Podsakoff, and M. A. LePine. 2005. "A meta-analytic test of the challenge stressor-hindrance stressor framework: An explanation for inconsistent relationships among 
stressors and performance." Academy of Management Journal, 48(5), 764-775. doi: 10.2307/20159696.

Lim, V. K. G. 1997. "Moderating effects of work-based support on the relationship between job insecurity and its consequences." Work and Stress, 11, 251-266. https://doi.org/10.1080/02678379708256839.

Loader, C. R. 1999. Bandwidth Selection: Classical or Plug-in? The Annals of Statistics. 27(2): 415438. doi: 10.1214/aos/1018031201

Lozza, E., Castiglioni, C., and A. Bonanomi. 2017. "The effects of changes in job insecurity on daily consumption and major life decisions. Economic and Industrial Democracy." Advance online publication. Doi: 10.1177/0143831X17731611

Lubke, C., and M. Erlinghagen, 2014. "Self-perceived job insecurity across Europe over time: Does changing context matter?." Journal of European Social Policy, 24(4): 319-336. doi: $10.1177 / 0958928714538215$.

Mauno, S., and U. Kinnunen, 1999. "Job insecurity and well-being: A longitudinal study among male and female employees in Finland. Community." Work and Family, 2(2): 147-171. doi: $10.1080 / 13668809908413938$.

Maurin, E., and F. Postel-Vinay. 2005. "The European job-security gap.” Work and Occupations, 32: 229-252. doi: 10.1177/0730888405274603

Melly, B. 2005. "Decomposition of differences in distribution using quantile regression." Labour Economics, 12: 577-590. doi: 10.1016/j.labeco.2005.05.006.

Näswall, K. and H. De Witte, 2003. "Who feels insecure in Europe? Predicting job insecurity from background variables." Economic and Industrial Democracy, 24(2): 189-215. doi: 10.1177/0143831X03024002003

Nätti, J., Happonen, M., Kinnunen, U. and S.Mauno 2005. “Job Insecurity, temporary work and trade union membership in Finland 1977-2003." in Job insecurity, union involvement and union activism edited by H. De Witte, 11-48. Aldershot: Ashgate. 
Oaxaca, R. 1973. "Male-Female Wage Differentials in Urban Labour Markets.” International Economic Review 14: 693-709. doi: 10.2307/2525981.

OECD. 2016. Employment Outlook. OECD.

Piccoli, B., Callea, A., Urbini, F., Chirumbolo, A., Ingusci, E., and H. De Witte. 2017. "Job insecurity and performance: the mediating role of organizational identification." Personnel Review, 46(8): 1508-1522. doi: 10.1108/PR-05-2016-0120.

Reisel, W. D., Chia, S. L., Maloles III, C. M., and Jr, J. W. Slocum. 2007. "The effects of job insecurity on satisfaction and perceived organizational performance.” Journal of Leadership and Organizational Studies, 14(2): 106-116. doi: 10.1177/1071791907308055

Sacchi S. 2018. "The Italian Welfare State in the Crisis: Learning to Adjust?"” South European Society and Politics, 23 (1): 29-46. doi: 10.1080/13608746.2018.1433478.

Sestito P. and E.Viviano 2018, "Firing costs and firm hiring: evidence from an Italian reform." Economic Policy, 33(93): 101-130. doi: 10.1093/epolic/eix018.

Sheather S. J. 2004. Density Estimation. Statistical Science 19: 588-597.

Stander, M. W. and Rothmann, S. 2010. "Psychological empowerment, job insecurity and employee engagement." SA Journal of Industrial Psychology, 36(1): 1-8. doi: 10.1177/0972150913515589.

Sverke, M., and J. Hellgren. 2002. "The nature of job insecurity: Understanding employment insecurity on the brink of anewmillennium." Applied Psychology, 51: 23-42. doi: 10.1111/1464-0597.0077z.

Sverke, M., Hellgren, J., and K. Näswall. 2002. "No security: A meta-analysis and review of job insecurity and its consequences." Journal of Occupational Health Psychology, 7: 242264.doi: 10.1037/1076-8998.7.3.242. 


\section{APPENDIX}

Table 3A

OLS and Quantile Regressions estimates. Job Insecurity:no

\begin{tabular}{|c|c|c|c|c|c|c|c|c|c|c|}
\hline & OLS & $\mathrm{q} 10$ & $\mathrm{q} 20$ & $\mathrm{q} 30$ & $\mathrm{q} 40$ & q50 & $\mathrm{q} 60$ & q70 & $\mathrm{q} 80$ & q90 \\
\hline \multirow[t]{2}{*}{ age } & $0.015^{*}$ & $0.031 * *$ & $0.021 * * *$ & 0.010 & $0.017 * *$ & $0.015^{* * *}$ & 0.009 & $0.018^{* *}$ & 0.018 & $0.022 *$ \\
\hline & $(0.009)$ & $(0.014)$ & $(0.007)$ & $(0.007)$ & $(0.007)$ & $(0.007)$ & $(0.008)$ & $(0.009)$ & $(0.012)$ & $(0.012)$ \\
\hline \multirow[t]{2}{*}{ age_sq } & -0.000 & $-0.000^{* *}$ & $-0.000 * * *$ & -0.000 & $-0.000 *$ & $-0.000 *$ & -0.000 & $-0.000 *$ & -0.000 & -0.000 \\
\hline & $(0.000)$ & $(0.000)$ & $(0.000)$ & $(0.000)$ & $(0.000)$ & $(0.000)$ & $(0.000)$ & $(0.000)$ & $(0.000)$ & $(0.000)$ \\
\hline \multirow[t]{2}{*}{ male } & $0.153 * * *$ & $0.162 * * *$ & $0.155 * * *$ & $0.138 * * *$ & $0.136 * * *$ & $0.129 * * *$ & $0.133 * * *$ & $0.154 * * *$ & $0.161 * * *$ & $0.162 * * *$ \\
\hline & $(0.019)$ & $(0.034)$ & $(0.023)$ & $(0.024)$ & $(0.032)$ & $(0.022)$ & $(0.024)$ & $(0.019)$ & $(0.025)$ & $(0.022)$ \\
\hline \multirow[t]{2}{*}{ make_ends_meet_1 } & $0.101^{* * * *}$ & $0.160^{* * * *}$ & $0.122 * * *$ & $0.079 * * *$ & $0.086 * * *$ & $0.099 * * *$ & $0.086 * * *$ & $0.079 * * *$ & $0.069 * *$ & 0.047 \\
\hline & $(0.020)$ & $(0.034)$ & $(0.031)$ & $(0.023)$ & $(0.021)$ & $(0.021)$ & $(0.016)$ & $(0.022)$ & $(0.027)$ & $(0.037)$ \\
\hline \multirow[t]{2}{*}{ make_ends_meet_2 } & $0.185 * * *$ & $0.209 * * *$ & $0.177 * * *$ & $0.150^{* * *}$ & $0.141^{* * *}$ & $0.143 * * *$ & $0.134 * * *$ & $0.131 * * *$ & $0.164 * * *$ & $0.217 * * *$ \\
\hline & $(0.026)$ & $(0.028)$ & $(0.040)$ & $(0.030)$ & $(0.030)$ & $(0.028)$ & $(0.025)$ & $(0.026)$ & $(0.044)$ & $(0.061)$ \\
\hline \multirow[t]{2}{*}{ edu_fath } & $0.020^{*}$ & 0.005 & 0.004 & $0.012 *$ & $0.016^{* *}$ & $0.013 * *$ & $0.013^{*}$ & 0.019 & 0.016 & $0.043 * * *$ \\
\hline & $(0.011)$ & $(0.018)$ & $(0.009)$ & $(0.007)$ & $(0.007)$ & $(0.005)$ & $(0.008)$ & $(0.013)$ & $(0.013)$ & $(0.014)$ \\
\hline \multirow[t]{2}{*}{ work_exp } & $0.005 * * *$ & $0.007 * *$ & $0.006 * * *$ & $0.006 * * *$ & $0.003^{* *}$ & $0.004 *$ & $0.003^{*}$ & $0.003^{*}$ & 0.003 & 0.003 \\
\hline & $(0.002)$ & $(0.003)$ & $(0.001)$ & $(0.002)$ & $(0.002)$ & $(0.002)$ & $(0.002)$ & $(0.002)$ & $(0.002)$ & $(0.002)$ \\
\hline \multirow[t]{2}{*}{ pasted } & $0.053 * * *$ & $0.055 * * *$ & $0.055 * * *$ & $0.050^{* * *}$ & $0.041^{* * *}$ & $0.050^{* * *}$ & $0.049 * * *$ & $0.046^{* * * *}$ & $0.057 * * *$ & $0.059 * * *$ \\
\hline & $(0.007)$ & $(0.010)$ & $(0.009)$ & $(0.007)$ & $(0.003)$ & $(0.006)$ & $(0.007)$ & $(0.008)$ & $(0.012)$ & $(0.012)$ \\
\hline \multirow[t]{2}{*}{ full } & $0.408^{* * * *}$ & $0.574 * * * *$ & $0.496 * * *$ & $0.483 * * *$ & $0.428 * * *$ & $0.382 * * *$ & $0.344 * * *$ & $0.344 * * *$ & $0.315 * * *$ & $0.273 * * *$ \\
\hline & $(0.025)$ & $(0.037)$ & $(0.040)$ & $(0.027)$ & $(0.033)$ & $(0.025)$ & $(0.023)$ & $(0.020)$ & $(0.022)$ & $(0.046)$ \\
\hline \multirow[t]{2}{*}{ perm } & $0.093 * * *$ & 0.099* & $0.153^{* * * *}$ & $0.112 * * *$ & $0.122 * * *$ & $0.097 * * *$ & $0.082 * * *$ & $0.080 * *$ & 0.041 & 0.035 \\
\hline & $(0.026)$ & $(0.055)$ & $(0.041)$ & $(0.024)$ & $(0.023)$ & $(0.019)$ & $(0.020)$ & $(0.031)$ & $(0.045)$ & $(0.040)$ \\
\hline \multirow[t]{2}{*}{ mobility_1 } & $-0.060 * * *$ & -0.026 & -0.032 & -0.022 & -0.032 & $-0.067^{* * * *}$ & $-0.070 * * *$ & $-0.078 * * *$ & $-0.083^{* *}$ & -0.066 \\
\hline & $(0.023)$ & $(0.033)$ & $(0.028)$ & $(0.023)$ & $(0.024)$ & $(0.026)$ & $(0.026)$ & $(0.026)$ & $(0.040)$ & $(0.045)$ \\
\hline \multirow[t]{2}{*}{ mobility_2 } & $-0.068 * * *$ & $-0.109 * * *$ & $-0.054 *$ & -0.040 & -0.028 & $-0.051^{* *}$ & $-0.051 * * *$ & $-0.054 * *$ & $-0.077 * *$ & $-0.053 *$ \\
\hline & $(0.023)$ & $(0.040)$ & $(0.032)$ & $(0.028)$ & $(0.028)$ & $(0.024)$ & $(0.019)$ & $(0.022)$ & $(0.037)$ & $(0.029)$ \\
\hline \multirow[t]{2}{*}{ mobility_3 } & -0.029 & -0.066 & -0.043 & -0.022 & -0.005 & -0.023 & -0.042 & -0.017 & -0.034 & -0.027 \\
\hline & $(0.028)$ & $(0.053)$ & $(0.036)$ & $(0.028)$ & $(0.031)$ & $(0.023)$ & $(0.030)$ & $(0.032)$ & $(0.045)$ & $(0.043)$ \\
\hline \multirow[t]{2}{*}{ stability } & -0.011 & -0.021 & -0.004 & -0.004 & -0.010 & -0.013 & $-0.018^{*}$ & -0.020 & 0.005 & -0.001 \\
\hline & $(0.012)$ & $(0.025)$ & $(0.020)$ & $(0.017)$ & $(0.015)$ & $(0.014)$ & $(0.010)$ & $(0.015)$ & $(0.012)$ & $(0.020)$ \\
\hline \multirow[t]{2}{*}{ training } & $0.058 * * *$ & $0.090 * * *$ & $0.064 * * *$ & $0.044 * *$ & $0.038^{*}$ & $0.040^{*}$ & $0.044 * * *$ & $0.047 * *$ & $0.056^{*}$ & 0.015 \\
\hline & $(0.017)$ & $(0.025)$ & $(0.020)$ & $(0.020)$ & $(0.022)$ & $(0.023)$ & $(0.013)$ & $(0.021)$ & $(0.031)$ & $(0.041)$ \\
\hline \multirow[t]{2}{*}{ supervisor } & $0.098 * * *$ & 0.029 & $0.060 * * *$ & $0.081 * * *$ & $0.082 * * *$ & $0.098 * * *$ & $0.115^{* * * *}$ & $0.112 * * *$ & $0.111 * * *$ & $0.161 * * *$ \\
\hline & $(0.019)$ & $(0.028)$ & $(0.022)$ & $(0.013)$ & $(0.014)$ & $(0.018)$ & $(0.013)$ & $(0.008)$ & $(0.025)$ & $(0.025)$ \\
\hline \multirow[t]{2}{*}{ telework } & $0.082 * * *$ & 0.077 & 0.051 & 0.038 & $0.058 * *$ & 0.057 & $0.084 * *$ & $0.083 * * *$ & $0.085^{*}$ & 0.059 \\
\hline & $(0.029)$ & (0.074) & $(0.035)$ & $(0.026)$ & $(0.023)$ & $(0.039)$ & $(0.042)$ & $(0.032)$ & $(0.046)$ & $(0.041)$ \\
\hline \multirow[t]{2}{*}{ contr } & 0.098 & $0.190 *$ & 0.121 & $0.133^{* *}$ & 0.058 & 0.058 & 0.063 & -0.021 & -0.002 & 0.034 \\
\hline & $(0.063)$ & $(0.111)$ & $(0.097)$ & $(0.058)$ & $(0.055)$ & $(0.052)$ & $(0.057)$ & $(0.051)$ & $(0.030)$ & $(0.055)$ \\
\hline routine & $-0.055^{* * * *}$ & $-0.061 *$ & -0.045 & -0.047 & $-0.065^{* * *}$ & $-0.069^{* * * *}$ & $-0.075^{* * * *}$ & $-0.070^{* *}$ & $-0.072 * * *$ & $-0.074 * * * *$ \\
\hline & $(0.020)$ & $(0.035)$ & $(0.037)$ & $(0.031)$ & $(0.015)$ & $(0.024)$ & $(0.023)$ & $(0.032)$ & $(0.019)$ & $(0.024)$ \\
\hline mismatch & -0.030 & 0.003 & -0.030 & -0.023 & -0.025 & $-0.035^{*}$ & -0.034 & -0.023 & -0.037 & -0.019 \\
\hline & $(0.019)$ & $(0.021)$ & $(0.019)$ & $(0.020)$ & $(0.024)$ & $(0.022)$ & $(0.025)$ & $(0.021)$ & $(0.025)$ & $(0.040)$ \\
\hline stress & $0.078 * * *$ & $0.147 * * *$ & $0.101^{* * *}$ & $0.077^{* * * *}$ & $0.050^{* * *}$ & $0.055^{* * * *}$ & $0.056^{* * * *}$ & $0.045^{* *}$ & $0.043 * *$ & $0.082 * * *$ \\
\hline & $(0.017)$ & $(0.027)$ & $(0.025)$ & $(0.013)$ & $(0.017)$ & $(0.013)$ & $(0.019)$ & $(0.021)$ & $(0.021)$ & $(0.025)$ \\
\hline unionsize & $0.000 * *$ & 0.000 & 0.000 & $0.000 *$ & 0.000 & 0.000 & 0.000 & 0.000 & 0.000 & $0.000 * *$ \\
\hline & $(0.000)$ & $(0.000)$ & $(0.000)$ & $(0.000)$ & $(0.000)$ & $(0.000)$ & $(0.000)$ & $(0.000)$ & $(0.000)$ & $(0.000)$ \\
\hline mezzogiorno & $-0,033$ & -0.050 & -0.024 & -0.027 & -0.023 & -0.014 & -0.019 & -0.024 & -0.024 & -0.026 \\
\hline & $(0.021)$ & $(0.050)$ & $(0.047)$ & $(0.039)$ & $(0.031)$ & $(0.029)$ & $(0.030)$ & $(0.036)$ & $(0.033)$ & $(0.036)$ \\
\hline _cons & $5.508 * * *$ & 4.569 **** & $5.012 * * *$ & $5.471 * * *$ & $5.571 * * *$ & $5.670 * * *$ & $5.863 * * *$ & $5.817 * * *$ & $5.934 * * *$ & $5.892 * * *$ \\
\hline & $(0.210)$ & $(0.352)$ & $(0.250)$ & $(0.146)$ & $(0.120)$ & $(0.147)$ & $(0.151)$ & $(0.174)$ & $(0.263)$ & $(0.369)$ \\
\hline Sectors & & & & & Yes & & & & & \\
\hline $\mathrm{N}$ & & & & & 1239 & & & & & \\
\hline Pseudo R2 & 0,557 & 0,446 & 0,403 & 0,375 & 0,351 & 0,337 & 0,325 & 0,315 & 0,316 & 0,332 \\
\hline
\end{tabular}


Table 3B

OLS and Quantile Regressions estimates. Job Insecurity:yes

\begin{tabular}{|c|c|c|c|c|c|c|c|c|c|c|}
\hline & OLS & $\mathrm{q} 10$ & $\mathrm{q} 20$ & $\mathrm{q} 30$ & $\mathrm{q} 40$ & $\mathrm{q} 50$ & $\mathrm{q} 60$ & $\mathrm{q} 70$ & q80 & $\mathrm{q} 90$ \\
\hline age & $\begin{array}{c}0.013^{* *} \\
(0.005)\end{array}$ & $\begin{array}{c}0.025^{* *} \\
(0.010)\end{array}$ & $\begin{array}{c}0.019 * * \\
(0.007)\end{array}$ & $\begin{array}{c}0.019 * * * \\
(0.005)\end{array}$ & $\begin{array}{c}0.017 * * * \\
(0.004)\end{array}$ & $\begin{array}{c}0.020 * * * \\
(0.003)\end{array}$ & $\begin{array}{c}0.019 * * * \\
(0.005)\end{array}$ & $\begin{array}{c}0.018^{* * * *} \\
(0.006)\end{array}$ & $\begin{array}{c}0.010 \\
(0.010)\end{array}$ & $\begin{array}{c}0.005 \\
(0.007)\end{array}$ \\
\hline age_sq & $\begin{array}{l}-0.000 \\
(0.000)\end{array}$ & $\begin{array}{c}-0.000^{* *} \\
(0.000)\end{array}$ & $\begin{array}{c}-0.000^{*} \\
(0.000)\end{array}$ & $\begin{array}{c}-0.000 * * * \\
(0.000)\end{array}$ & $\begin{array}{c}-0.000^{* * *} \\
(0.000)\end{array}$ & $\begin{array}{c}-0.000 \text { *** } \\
(0.000)\end{array}$ & $\begin{array}{c}-0.000 * * \\
(0.000)\end{array}$ & $\begin{array}{c}-0.000 * \\
(0.000)\end{array}$ & $\begin{array}{c}-0.000 \\
(0.000)\end{array}$ & $\begin{array}{c}0.000 \\
(0.000)\end{array}$ \\
\hline male & $\begin{array}{c}0.126^{* * * *} \\
(0.010)\end{array}$ & $\begin{array}{c}0.112^{* * * *} \\
(0.010)\end{array}$ & $\begin{array}{c}0.103^{* * *} \\
(0.009)\end{array}$ & $\begin{array}{c}0.113^{* * *} \\
(0.008)\end{array}$ & $\begin{array}{c}0.111^{* * *} \\
(0.008)\end{array}$ & $\begin{array}{c}0.099 * * * \\
(0.011)\end{array}$ & $\begin{array}{c}0.109 * * * \\
(0.013)\end{array}$ & $\begin{array}{c}0.115^{* * * *} \\
(0.009)\end{array}$ & $\begin{array}{c}0.125 * * * \\
(0.014)\end{array}$ & $\begin{array}{c}0.143 * * * \\
(0.015)\end{array}$ \\
\hline make_ends_meet_1 & $\begin{array}{c}0.082^{* * * *} \\
(0.013)\end{array}$ & $\begin{array}{c}0.093^{* * *} * \\
(0.022)\end{array}$ & $\begin{array}{c}0.072 * * * \\
(0.018)\end{array}$ & $\begin{array}{c}0.067 * * * \\
(0.015)\end{array}$ & $\begin{array}{c}0.068^{* * *} \\
(0.012)\end{array}$ & $\begin{array}{c}0.064 * * * \\
(0.016)\end{array}$ & $\begin{array}{c}0.069 * * * \\
(0.014)\end{array}$ & $\begin{array}{c}0.073 * * * \\
(0.014)\end{array}$ & $\begin{array}{c}0.070 * * * \\
(0.014)\end{array}$ & $\begin{array}{l}0.039 * \\
(0.023)\end{array}$ \\
\hline make_ends_meet_2 & $\begin{array}{c}0.173^{* * * *} \\
(0.014)\end{array}$ & $\begin{array}{c}0.156^{* * *} * \\
(0.025)\end{array}$ & $\begin{array}{c}0.141 * * * \\
(0.014)\end{array}$ & $\begin{array}{c}0.131^{* * *} \\
(0.018)\end{array}$ & $\begin{array}{c}0.137 * * * \\
(0.015)\end{array}$ & $\begin{array}{c}0.139 * * * \\
(0.020)\end{array}$ & $\begin{array}{c}0.139 * * * \\
(0.019)\end{array}$ & $\begin{array}{c}0.146^{* * * *} \\
(0.019)\end{array}$ & $\begin{array}{c}0.156^{* * * *} \\
(0.018)\end{array}$ & $\begin{array}{c}0.141 * * * \\
(0.031)\end{array}$ \\
\hline edu_fath & $\begin{array}{c}0.018^{* * * *} \\
(0.005)\end{array}$ & $\begin{array}{c}0.004 \\
(0.010)\end{array}$ & $\begin{array}{c}0.008 \\
(0.007)\end{array}$ & $\begin{array}{c}0.015^{* * *} \\
(0.005)\end{array}$ & $\begin{array}{c}0.016^{* * * *} \\
(0.004)\end{array}$ & $\begin{array}{c}0.014 * * * \\
(0.005)\end{array}$ & $\begin{array}{c}0.016 * * \\
(0.007)\end{array}$ & $\begin{array}{c}0.019 * * * \\
(0.007)\end{array}$ & $\begin{array}{c}0.021 * * * \\
(0.006)\end{array}$ & $\begin{array}{c}0.020 * * \\
(0.008)\end{array}$ \\
\hline work_exp & $\begin{array}{l}0.002 * \\
(0.001)\end{array}$ & $\begin{array}{c}0.002 \\
(0.001)\end{array}$ & $\begin{array}{c}0.002 * * * \\
(0.001)\end{array}$ & $\begin{array}{c}0.002 * * * \\
(0.001)\end{array}$ & $\begin{array}{c}0.003 * * * \\
(0.001)\end{array}$ & $\begin{array}{c}0.003 * * * \\
(0.001)\end{array}$ & $\begin{array}{c}0.002 * * \\
(0.001)\end{array}$ & $\begin{array}{c}0.002 * \\
(0.001)\end{array}$ & $\begin{array}{c}0.001 \\
(0.001)\end{array}$ & $\begin{array}{c}0.000 \\
(0.001)\end{array}$ \\
\hline pasted & $\begin{array}{c}0.059 * * * \\
(0.004)\end{array}$ & $\begin{array}{c}0.050^{* * * *} \\
(0.005)\end{array}$ & $\begin{array}{c}0.052^{* * * *} \\
(0.004)\end{array}$ & $\begin{array}{c}0.048^{* * * *} \\
(0.003)\end{array}$ & $\begin{array}{c}0.049 * * * \\
(0.004)\end{array}$ & $\begin{array}{c}0.052 * * * \\
(0.003)\end{array}$ & $\begin{array}{c}0.054 * * * \\
(0.002)\end{array}$ & $\begin{array}{c}0.057 * * * \\
(0.003)\end{array}$ & $\begin{array}{c}0.061 * * * \\
(0.003)\end{array}$ & $\begin{array}{c}0.076^{* * * *} \\
(0.007)\end{array}$ \\
\hline full & $\begin{array}{c}0.393^{* * * *} \\
(0.016)\end{array}$ & $\begin{array}{c}0.586^{* * * *} \\
(0.036)\end{array}$ & $\begin{array}{c}0.494 * * * \\
(0.029)\end{array}$ & $\begin{array}{c}0.418^{* * * *} \\
(0.023)\end{array}$ & $\begin{array}{c}0.383^{* * * *} \\
(0.016)\end{array}$ & $\begin{array}{c}0.356^{* * * *} \\
(0.012)\end{array}$ & $\begin{array}{c}0.333 * * * \\
(0.011)\end{array}$ & $\begin{array}{c}0.307 * * * \\
(0.012)\end{array}$ & $\begin{array}{c}0.295^{* * *} \\
(0.015)\end{array}$ & $\begin{array}{c}0.268 * * * \\
(0.026)\end{array}$ \\
\hline perm & $\begin{array}{l}0.060 * \\
(0.032)\end{array}$ & $\begin{array}{c}0.119 \\
(0.082)\end{array}$ & $\begin{array}{c}0.072 * * \\
(0.035)\end{array}$ & $\begin{array}{c}0.059 * * * \\
(0.019)\end{array}$ & $\begin{array}{c}0.068 * * * \\
(0.020)\end{array}$ & $\begin{array}{c}0.063 * * * \\
(0.014)\end{array}$ & $\begin{array}{c}0.073 * * * \\
(0.016)\end{array}$ & $\begin{array}{c}0.070 * * * \\
(0.020)\end{array}$ & $\begin{array}{l}0.079^{*} \\
(0.044)\end{array}$ & $\begin{array}{c}0.029 \\
(0.050)\end{array}$ \\
\hline mobility_1 & $\begin{array}{l}-0.018 \\
(0.011)\end{array}$ & $\begin{array}{l}-0.021 \\
(0.016)\end{array}$ & $\begin{array}{c}-0.033^{* * *} \\
(0.008)\end{array}$ & $\begin{array}{c}-0.035^{* * *} \\
(0.013)\end{array}$ & $\begin{array}{c}-0.025^{* *} \\
(0.012)\end{array}$ & $\begin{array}{c}-0.023^{*} \\
(0.013)\end{array}$ & $\begin{array}{l}-0.019 \\
(0.015)\end{array}$ & $\begin{array}{c}-0.011 \\
(0.019)\end{array}$ & $\begin{array}{l}-0.013 \\
(0.014)\end{array}$ & $\begin{array}{l}-0.019 \\
(0.017)\end{array}$ \\
\hline mobility_2 & $\begin{array}{c}-0.022 * \\
(0.012)\end{array}$ & $\begin{array}{c}-0.029 * * \\
(0.014)\end{array}$ & $\begin{array}{c}-0.033^{* * *} \\
(0.009)\end{array}$ & $\begin{array}{c}-0.043 * * * \\
(0.012)\end{array}$ & $\begin{array}{c}-0.037 * * * \\
(0.014)\end{array}$ & $\begin{array}{c}-0.036^{* *} \\
(0.014)\end{array}$ & $\begin{array}{l}-0.022 \\
(0.019)\end{array}$ & $\begin{array}{l}-0.024 \\
(0.015)\end{array}$ & $\begin{array}{l}-0.007 \\
(0.016)\end{array}$ & $\begin{array}{c}0.003 \\
(0.023)\end{array}$ \\
\hline mobility_3 & $\begin{array}{c}-0.036^{* *} \\
(0.017)\end{array}$ & $\begin{array}{l}-0.039 \\
(0.024)\end{array}$ & $\begin{array}{c}-0.049 * * * \\
(0.018)\end{array}$ & $\begin{array}{c}-0.061 * * * \\
(0.013)\end{array}$ & $\begin{array}{c}-0.057 * * * \\
(0.016)\end{array}$ & $\begin{array}{c}-0.047 * * * \\
(0.017)\end{array}$ & $\begin{array}{l}-0.036 \\
(0.022)\end{array}$ & $\begin{array}{c}-0.033^{* *} \\
(0.014)\end{array}$ & $\begin{array}{l}-0.013 \\
(0.010)\end{array}$ & $\begin{array}{l}-0.015 \\
(0.029)\end{array}$ \\
\hline stability & $\begin{array}{c}0.010 \\
(0.007)\end{array}$ & $\begin{array}{c}0.006 \\
(0.007)\end{array}$ & $\begin{array}{l}-0.002 \\
(0.007)\end{array}$ & $\begin{array}{c}0.003 \\
(0.009)\end{array}$ & $\begin{array}{l}-0.004 \\
(0.007)\end{array}$ & $\begin{array}{l}-0.002 \\
(0.007)\end{array}$ & $\begin{array}{c}0.005 \\
(0.009)\end{array}$ & $\begin{array}{c}0.001 \\
(0.008)\end{array}$ & $\begin{array}{c}0.011 \\
(0.009)\end{array}$ & $\begin{array}{c}0.020 * * \\
(0.009)\end{array}$ \\
\hline training & $\begin{array}{c}0.043^{* * * *} \\
(0.009)\end{array}$ & $\begin{array}{c}0.027 * \\
(0.015)\end{array}$ & $\begin{array}{c}0.038 * * * \\
(0.012)\end{array}$ & $\begin{array}{c}0.033^{* * *} * \\
(0.010)\end{array}$ & $\begin{array}{c}0.034 * * * \\
(0.008)\end{array}$ & $\begin{array}{c}0.037 * * * \\
(0.007)\end{array}$ & $\begin{array}{c}0.028 * * \\
(0.012)\end{array}$ & $\begin{array}{c}0.025^{* *} \\
(0.010)\end{array}$ & $\begin{array}{c}0.034 * * * \\
(0.011)\end{array}$ & $\begin{array}{c}0.033 * * * \\
(0.013)\end{array}$ \\
\hline supervisor & $\begin{array}{c}0.118^{* * * *} \\
(0.009)\end{array}$ & $\begin{array}{c}0.085^{* * * *} \\
(0.009)\end{array}$ & $\begin{array}{c}0.075^{* * * *} \\
(0.005)\end{array}$ & $\begin{array}{c}0.087 * * * \\
(0.006)\end{array}$ & $\begin{array}{c}0.090^{* * * *} \\
(0.008)\end{array}$ & $\begin{array}{c}0.092 * * * \\
(0.011)\end{array}$ & $\begin{array}{c}0.099 * * * \\
(0.014)\end{array}$ & $\begin{array}{c}0.115^{* * * *} \\
(0.014)\end{array}$ & $\begin{array}{c}0.147 * * * \\
(0.016)\end{array}$ & $\begin{array}{c}0.187 * * * \\
(0.021)\end{array}$ \\
\hline telework & $\begin{array}{c}0.058 * * * \\
(0.013)\end{array}$ & $\begin{array}{l}0.044^{*} \\
(0.025)\end{array}$ & $\begin{array}{c}0.045^{* * * *} \\
(0.014)\end{array}$ & $\begin{array}{c}0.044 * * * \\
(0.014)\end{array}$ & $\begin{array}{c}0.055^{* * * *} \\
(0.012)\end{array}$ & $\begin{array}{c}0.050 \text { *** } \\
(0.009)\end{array}$ & $\begin{array}{c}0.063 * * * \\
(0.011)\end{array}$ & $\begin{array}{c}0.068 * * * \\
(0.012)\end{array}$ & $\begin{array}{c}0.071 * * * \\
(0.015)\end{array}$ & $\begin{array}{c}0.057 * * \\
(0.023)\end{array}$ \\
\hline contr & $\begin{array}{c}0.074 \\
(0.049)\end{array}$ & $\begin{array}{c}0.129 \\
(0.162)\end{array}$ & $\begin{array}{c}0.025 \\
(0.030)\end{array}$ & $\begin{array}{c}0.046^{* *} \\
(0.020)\end{array}$ & $\begin{array}{l}0.057 * \\
(0.034)\end{array}$ & $\begin{array}{c}0.071 * * \\
(0.033)\end{array}$ & $\begin{array}{c}0.085 * * \\
(0.039)\end{array}$ & $\begin{array}{l}0.071^{*} \\
(0.042)\end{array}$ & $\begin{array}{c}0.049 \\
(0.046)\end{array}$ & $\begin{array}{c}0.082 \\
(0.087)\end{array}$ \\
\hline routine & $\begin{array}{c}-0.059^{* * *} \\
(0.010)\end{array}$ & $\begin{array}{c}-0.051 * * * \\
(0.017)\end{array}$ & $\begin{array}{c}-0.045^{* * *} \\
(0.013)\end{array}$ & $\begin{array}{c}-0.053 * * * \\
(0.011)\end{array}$ & $\begin{array}{c}-0.057 * * * \\
(0.007)\end{array}$ & $\begin{array}{c}-0.053^{* * *} * \\
(0.009)\end{array}$ & $\begin{array}{c}-0.062^{* * *} \\
(0.011)\end{array}$ & $\begin{array}{c}-0.062^{* * * *} \\
(0.010)\end{array}$ & $\begin{array}{c}-0.054^{* * * *} \\
(0.010)\end{array}$ & $\begin{array}{c}-0.078^{* * * *} \\
(0.017)\end{array}$ \\
\hline mismatch & $\begin{array}{c}-0.029 * * \\
(0.011)\end{array}$ & $\begin{array}{c}-0.050 * * * \\
(0.016)\end{array}$ & $\begin{array}{c}-0.021 * * * \\
(0.007)\end{array}$ & $\begin{array}{c}-0.014 * * * \\
(0.004)\end{array}$ & $\begin{array}{c}-0.011^{*} \\
(0.006)\end{array}$ & $\begin{array}{l}-0.004 \\
(0.005)\end{array}$ & $\begin{array}{c}-0.008 \\
(0.011)\end{array}$ & $\begin{array}{l}-0.006 \\
(0.014)\end{array}$ & $\begin{array}{l}-0.003 \\
(0.014)\end{array}$ & $\begin{array}{l}-0.011 \\
(0.025)\end{array}$ \\
\hline stress & $\begin{array}{c}0.041^{*} * * \\
(0.009)\end{array}$ & $\begin{array}{c}0.029 * * * \\
(0.008)\end{array}$ & $\begin{array}{c}0.030^{* *} \\
(0.012)\end{array}$ & $\begin{array}{c}0.037 * * * \\
(0.010)\end{array}$ & $\begin{array}{c}0.030 * * * \\
(0.011)\end{array}$ & $\begin{array}{l}0.025^{*} \\
(0.015)\end{array}$ & $\begin{array}{c}0.018 \\
(0.015)\end{array}$ & $\begin{array}{l}0.022 * \\
(0.014)\end{array}$ & $\begin{array}{c}0.026 * * \\
(0.013)\end{array}$ & $\begin{array}{c}0.033 * * \\
(0.014)\end{array}$ \\
\hline unionsize & $\begin{array}{c}0.000^{* * * *} \\
(0.000)\end{array}$ & $\begin{array}{c}0.000^{* * * *} \\
(0.000)\end{array}$ & $\begin{array}{c}0.000^{* * * *} \\
(0.000)\end{array}$ & $\begin{array}{c}0.000^{* * * *} \\
(0.000)\end{array}$ & $\begin{array}{c}0.000^{* * * *} \\
(0.000)\end{array}$ & $\begin{array}{c}0.000 * * \\
(0.000)\end{array}$ & $\begin{array}{c}0.000 * * * \\
(0.000)\end{array}$ & $\begin{array}{c}0.000 * * * \\
(0.000)\end{array}$ & $\begin{array}{c}0.000 * * * \\
(0.000)\end{array}$ & $\begin{array}{l}0.000^{*} \\
(0.000)\end{array}$ \\
\hline mezzogiorno & $\begin{array}{l}-0.011 \\
(0.010)\end{array}$ & $\begin{array}{l}-0.024 \\
(0.016)\end{array}$ & $\begin{array}{c}-0.009 \\
(0.011)\end{array}$ & $\begin{array}{c}-0.023 * \\
(0.012)\end{array}$ & $\begin{array}{l}-0.006 \\
(0.010)\end{array}$ & $\begin{array}{c}0.003 \\
(0.013)\end{array}$ & $\begin{array}{c}0.011 \\
(0.011)\end{array}$ & $\begin{array}{c}0.012 \\
(0.012)\end{array}$ & $\begin{array}{c}0.014 \\
(0.013)\end{array}$ & $\begin{array}{l}-0.011 \\
(0.028)\end{array}$ \\
\hline _cons & $\begin{array}{c}5.732 * * * \\
(0.143)\end{array}$ & $\begin{array}{c}4.838^{* * * *} \\
(0.313)\end{array}$ & $\begin{array}{c}5.487 * * * \\
(0.150)\end{array}$ & $\begin{array}{c}5.683 * * * \\
(0.079)\end{array}$ & $\begin{array}{c}5.755^{* * *} \\
(0.066)\end{array}$ & $\begin{array}{c}5.748^{* * * *} \\
(0.062)\end{array}$ & $\begin{array}{c}5.784 * * * \\
(0.073)\end{array}$ & $\begin{array}{c}5.881 * * * \\
(0.117)\end{array}$ & $\begin{array}{c}6.094 * * * \\
(0.271)\end{array}$ & $\begin{array}{c}6.320 * * * \\
(0.194)\end{array}$ \\
\hline Sectors & \multicolumn{10}{|c|}{ Yes } \\
\hline $\begin{array}{l}\mathrm{N} \\
\text { Pseudo R2 }\end{array}$ & 0,493 & 0,370 & 0,334 & 0,315 & $\begin{array}{r}4155 \\
0,300\end{array}$ & 0,285 & 0,286 & 0,293 & 0,303 & 0,341 \\
\hline
\end{tabular}

